\title{
Effect of Five Star Hotel Restaurant Cook's Emotional labor on Job Satisfaction and Customer Orientation
}

\author{
Hey-Sook KIM \\ Professor, Graduate School of Smart intergrated, Kwangwoon University, South Korea \\ E-mail: 1yorisa@naver.com
}

Received: 12 May 2020. Revised: 01 June 2020. Accepted: 04 June 2020.

\begin{abstract}
Purpose - The current study analyzes effects of hotel restaurant cook's emotional labor on job satisfaction and customer orientation.

Research design and methodology - In order to achieve the current study's goal, sample was extracted targeting cooks working in 5-stars hotels located in Seoul considering spatial and time limitation. Method of research was direct research method with survey. Survey was conducted from April 1st, 2018 to April 20, 2018 (approximately 20 days). Total of 300 surveys were distributed to cooks working in 5-stars hotels located in Seoul, and among those 250 surveys were returned. Among returned 250 surveys, 246 surveys.

Results - First, in order to test H1, effect of hotel restaurant cook's emotional labor on job satisfaction (satisfaction on superior and coworker) was analyzed. Second, in order to test H2, effect on hotel restaurant cook's emotional labor on job satisfaction (satisfaction on compensation and promotion) was analyzed. Third, satisfaction on superior and coworker had statistically significantly positive effect on customer orientation, while satisfaction on compensation and promotion did not have statistically significant effect.

Conclusions - First, deep acting had statistically significantly positive effect on job satisfaction (satisfaction on superior and coworker), while surface acting did not have statistically significant effect. Second, both deep and surface acting had statistically significantly positive effect on job satisfaction (satisfaction on compensation and promotion). Third, satisfaction on superior and coworker had statistically significantly positive effect on customer orientation, while satisfaction on compensation and promotion did not have statistically significant effect.
\end{abstract}

Keywords: Customer Orientation, Emotional labor, Job Satisfaction.

JEL Classification Code: C12, F81, J21, J23

(c) Copyright: The Author(s)

This is an Open Access article distributed under the terms of the Creative Commons Attribution Non-Commercial License (http://Creativecommons.org/licenses/by-nc/4.0/) which permits unrestricted noncommercial use, distribution, and reproduction in any medium, provided the original work is properly cited. 


\section{Introduction}

The In these days, it is generally understood that competence of workers associated to hotel's performance is not limited to hospitality technique or professionality. It can be deemed in this way with the fact that hotel worker's emotion or attitude acts as an important factor on their interrelationship with customers. As the importance of service utilizing hotel worker's emotion emerges recently, it has been perceived as a crucial method in securing service organization's competitive advantage.

To maximize profit of hotels, they must focus on foodservices which can produce profit, rather than relying on hotel room sales which is limited (Kim \& Choi, 2017). Also, as cost of beverages and food is relatively high resulting in small gross profit, quantitative goal is necessary for the maximized profit which connotes cost management factors (Woo, Seo, \& Cho, 2012).

In turn, it is needed to optimize the production efficiency by faithfully carrying out job of cooking department to maximize the profit of food services and hotel's management efficiency. To do so, cook's competence is essential along with an ability to look ahead. In other words, by providing foods produced with taste and nutrition through innovative competence to customers, amplified profit can be anticipated.

Service agreement with cook and customer brings place of mutual communication, which in turn forms relationship that affects cook's emotional labor, which then affects cook's job satisfaction and customer orientation. If there is no job satisfaction or weakened customer orientation, quality of cook's customer service deteriorates that deepens negative emotional labor, that further forms vicious cycle of aggravated job satisfaction and customer service. Lowered job satisfaction of extraordinary cook cheapens reputation of cooking department or hotel itself.

With change of environment of hotel cooks, role of cooking department to enhance hotel's foodsevices can be viewed vital. Food produced in hotel restaurant has high limitation of mechanization and automation, and most of the works are done by hands resulting in higher dependency on human resources compared to other occupations (Kim \& Chung, 2019). For enhanced quality of hotel's foodservices and superiority of hotel's competency, hotel cook's emotional labor, job satisfaction, and customer orientation are crucial to raise hotel's competitiveness.

Until now, there has been numerous researches on hotel worker's emotional labor; however, researches on hotel restaurant cook's emotional labor are lacking. Researches on emotional labor have been conducted on hotel, restaurants, flight attendant, call center customer representative, salesperson in department store, and clinical nurses. However, there is essentially no research on cook's emotional labor and customer orientation.

The current study analyzes effect of hotel restaurant cook's emotional labor on job satisfaction and effects of their job satisfaction on customer orientation. Based on the analysis, this study aims to suggest ways to manage hotel cook's human resources more efficiently and enhance their job satisfaction and customer orientation.

\section{Theoretical Background}

\subsection{Emotional labor}

Emotional labor was first studies by Hochschild (1983) and reconstructed by other researchers, and more focused researches on its leading variable and outcome variable have been conducted. As there are conflicting ideas on emotional labor, more diverse studies should be conducted (Ashforth \& Humphrey, 1993; Wharton, 1993; Brotheridge \& Grandey, 2002; Kim \& Han, 2013; Ko, 2013).

Hochschild (1983) suggests surface acting and deep acting as emotional labor's components. Those two can be differentiated by provider's acting method. In the study done by Ashforth and Humphrey (1993), new way of emotion expression, genuine emotion through which emotion felt is expressed as is, was suggested in addition to surface acting and deep acting.

In a research done by Wharton (1993) which shows positive result of emotional labor, there was correlation between emotional labor and job satisfaction. It was analyzed that since occupation with emotional labor is popular to those with personal traits of being comfortable with encountering people, conformity between tendency and job can result in job satisfaction. Ashforth and Humphrey (1993) stated that salesperson seemed to restrict and control his emotions; however, he did not need to make a huge effort for emotional labor as he tactically responded to customers routinely in his everyday life. In other words, when workers get used to emotional labor, they start to psychologically distance themselves from unpleasant situation. Also, it was deemed in the study done by Rafeli and Sutton (1987) that emotional labor workers who tended to smile constantly had low stress and high job satisfaction in general, which led to a conclusion that deep acting had a positive effect. 
On the other hand, studies on emotional labor commonly focus on negative effect of emotional labor. Hochschild (1983), through interviews and observations, viewed that flight attendants tended to reproach themselves and had difficulty in expressing their true emotions in their personal lives. Adelmann (1989), by comparing emotional labor worker cluster and workers with no emotional labor cluster, stated that emotional labor worker cluster had low job satisfaction and self-esteem and bad health condition, as well as depression. In the study done by Brotheridge and Grandey (2002), it was turned out that emotional labor decreased job satisfaction while increased job stress.

The following are the reviews of previous researches done on emotional labor. In Kim (2001)'s study, it was said that workers with emotional labor expressed emotions standardized by organizations, not their actual emotions, and they could have adverse effect such as emotional disharmony or depression. Baik (2003) conducted a research targeting hairstylists, and she explained that workers' work environment was focused on customers which led to workers' emotional stress from relationship with customers; in addition, there was high emotional labor as workers thought that they had low job stability. Choi, Lim, and Jung (2008), in their study about predisposing factors of call center worker's emotional labor, stated that job autonomy - among job characteristics - had significantly positive relationship with frequency of emotion expression, and work emotion - along personal characteristics - had significantly positive relationship with two levels of emotional labor. In the same manner, emotional consideration had significantly positive relationship with frequency of emotion expression, and emotional influence had significantly positive relationship with cautiousness of emotion expression.

Kim and Han (2012) stated that among effects of emotional labor of police officers on job stress and job satisfaction, emotional disharmony had positive effect on job satisfaction, while social support and emotional effort with job autonomy had negative effect on job stress. Also, Ko (2013), in his study on social workers' emotional labor, viewed that social workers in social welfare organization were asked to follow standardized expression while providing satisfactory service to clients and put efforts in emotion control to induce receptive emotion when client feels angry, unfriendly, or pessimistic.

Based on previous researches done by Hochschild (1983), Ashforth and Humphrey (1993), Grandey (2000), and Zapf (2002), the current study utilizes surface acting and deep acting as measurements of emotional labor.

\subsection{Job Satisfaction}

Job satisfaction is extent of positive personal attitude toward one's job. In other words, job satisfaction refers to one's emotional pleasantness and satisfaction from evaluation of work environment and work itself based on personal attitude, value, belief, and desire which affects job performance (Kwak, 2003). There are distinctions on opinion about job satisfaction among scholars. Hoppock (1935) defined job satisfaction as product of worker's psychological, physiological, and environmental satisfaction from his work. Job satisfaction was viewed as an aspect of attitude and was defined as one's attitude toward his job (McCornick \& Ilgen, 1980).

There is a common belief among scholars that job satisfaction is a way of emotional reaction. It turned out that job satisfaction was formed by consolidating opinions about job satisfaction factors - such as aptitude, skill, and value of the job - work environment, and compensation (Lee, 2004).

Job satisfaction can be said to be a difference between the quantity that one believes that he deserves and the quantity believed that he actually received. Thus, to enhance the extent of satisfaction, member's satisfaction of needs and motivation should be preceded. In terms of the extent of satisfaction, it can be defined as pleasant and positive emotion on job evaluation. It is a combined state of extent of satisfaction experienced by work, and member's psychological, physiological, and environmental situation. Also, it was defined as a member's state of achieving value of his job and accelerating it (Cho, Kim, \& Chae, 2006).

In the service industry, as member's job satisfaction leads to direct motivation of customer satisfaction, motivation of worker's job satisfaction has been an interest of researches for a long time. As for factors which have direct influence, there are suitability of job to one's image, predictability of job relationship, duty and harmony of job, sense of accomplishment, responsibility, growth, promotion, stability, self-fulfillment through performance, opportunity to show capability, authority and responsibility of job, service orientation, relationship with coworkers, knowledge of job, execution of company rule, welfare, and education and training (Smith et al., 2005; Kim, 2006; Kong et al., 2007).

In case of hotel restaurant, in previous studies about job satisfaction, compensation, recruitment, kitchen environment, along with well-established human resource management brings about high satisfaction (Cho et al., 2006; Lee et al., 2008). It was also said that the satisfaction was more influenced by high interaction between members' title and duty than frequency of customer encounter.

Based on the results of previous studies, job satisfaction is a form of members' attitude which reveals their emotional preference toward their jobs. In other words, it is extent to which an individual feels and evaluates his 
satisfaction with his work itself, satisfaction with compensation, opportunity to promote, supervision, satisfaction with coworkers, and working condition; and it has an important meaning on organization's productivity (Locke, 1976; Fisher, 2000; Jun, 2015; Megginson \& Chung, 1981).

In the current study, based on previous researches done by Jung (2014), Yoo (2016), and Wendy et al. (2005), uses satisfaction on superior and coworker, and satisfaction on compensation and promotion as measurements of job satisfaction.

\subsection{Customer Orientation}

Customer orientation has been a popular issue as corporations competitively aim for customer orientation and recognize customer satisfaction as their performance. The concept of customer orientation starts off by understanding customer's overall value chain, and it also includes prediction of future (Day \& Wensley, 1988). Customer orientation is a research focusing on immersion of subjects other than those covered earlier and signifies that research on immersion is being expanded to service domain (Kim, 2004).

Hoffman and Ingram (1992) defined customer orientation as corporation and worker's attitude to approach to customers in a manner that corresponds to customer's interest and explained it by differentiating with customer satisfaction. Brown et al. (2002) viewed customer orientation as one of individual variables which reflected service worker's tendency to satisfy customer's needs, which means that service worker putting himself in customer's shoes and executing corporation's effort. It was defined as tendency of corporation's general effort to enhance customer's profit. Allen et al. (2010) defined customer orientation as an act of corporation workers to heighten belief actions (deep acting) directly and to regulate negative belief actions (surface acting) and expression relationship.

If a service provider has a high customer orientation, he behaves to enhance customer satisfaction, and he can build a long-term relationship with customers. In turn, customer orientation can be used as a measurement variable to access customer satisfaction.

Before, previous studies constructed customer orientation as a single factor by approaching service provider's customer orientation to estimate customer satisfaction and understand corporation's outcome; however, studies now tend to construct customer orientation multi-dimensionally to measure workers psychological status in detail and service outcome.

Brown et al., (2002) defined customer orientation as worker's approach attitude and tendency to understand and tune himself to customer's need; and developed two measurements - enjoyment dimension and needs dimension of customer orientation. In other words, enjoyment dimension is extent to which worker naturally enjoys interacting and supporting customers, and needs dimension means belief of a worker who has ability to satisfy customer's need. Donavan et al. (2004) supplemented Brown et al. (2002)'s customer orientation dimensions and reconstructed components of customer orientation into 4 dimensions - need to pamper dimension, need to read customer's need dimension, need to deliver dimension, and need for personal relationship dimension.

Periatt et al. (2007) classified subfactors of customer orientation into individual help for purchase decision, preoccupation to comprehend customer's need, explanation of product's benefits, and usage of pressure tactics. Lee and Lee (2010) composed customer orientation with fulfillment of customer's need and customer service dimensions. Lee (2012) summarized it into service worker's tendency and belief to satisfy customer's need and organized it into subfactors of voluntary customer orientation and business customer orientation. Kim (2010) divided customer orientation into voluntary customer orientation where a worker behaves in customer's position and does his best, and business customer orientation where a worker provides all the useful information to customer. Jung (2014) constructed customer orientation into two dimensions: voluntary customer orientation - carrying out his role and duty without bring asked - and business customer orientation - providing useful information to customers, responding to customer's demand as honestly as possible, and delivering benefits of service clearly to customer.

The current study aims to measure hotel restaurant cook's customer orientation based on previous studies about hotel restaurant cook's customer orientation done by Periatt et al., (2007), Kim (2007), Lee (2012), Jung (2014), and Seo (2019) which reconstructed Brown et al. (2002)'s dimensions of customer orientation.

\section{Research Method}

\subsection{Setting Study Model}


This study analyzes effect of hotel restaurant cook's emotional labor on job satisfaction. It also analyzes effect of job satisfaction on customer orientation. Based on the analysis, the current study aims to suggest ways of managing hotel restaurant cook's human resources more efficiently and fundamental ways to enhance hotel restaurant cook's job satisfaction and customer orientation.

Research model set up based on contemplating preceding researches and references is as shown in Figure 1.

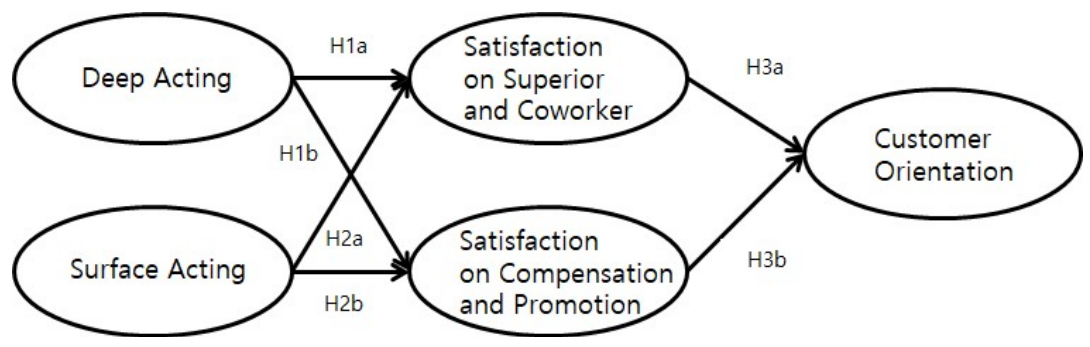

Figure 1: Research model

\subsection{Research Hypothesis}

\subsubsection{Relationship between Hotel Restaurant Cook's Emotional labor and Job Satisfaction (H1, H2)}

Based on preceding researches done by Hochschild (1983), Ashforth and Humphrey (1993), Hochschild (1979), Sager (1994), Spencer and Spencer (1993), Grandey (2000), Zapf (2002), Lee (2006), Sul and Choi (2007), Min (2007), Kwon (2010), Moon (2011), Seo and Yoo (2014), Cho (2014), Kwak (2015), and Yoo (2016), the current study was able to expect that hotel restaurant cook's emotional labor factor would have significant effect on job satisfaction. Therefore, the following hypotheses were established.

H1: Hotel restaurant cook's emotional labor will have effect on satisfaction on superior and coworker among job satisfaction

H1a: Hotel restaurant cook's deep acting will have effect on satisfaction on superior and coworker among job satisfaction

H1b: Hotel restaurant cook's surface acting will have effect on satisfaction on superior and coworker among job satisfaction

H2: Hotel restaurant cook's emotional labor will have effect on satisfaction on compensation and promotion among job satisfaction

H2a: Hotel restaurant cook's deep acting will have effect on satisfaction on compensation and promotion among job satisfaction

H2b: Hotel restaurant cook's surface acting will have effect on satisfaction on compensation and promotion among job satisfaction

\subsubsection{Relationship between Hotel Restaurant Cook’s Job Satisfaction and Customer Orientation}

Based on preceding researches done by Brown et al. (2002), Wendy et al. (2005), Periatt et al. (2007), Kim (2010), Lee (2012), Jung (2014), Jung (2014), and Yoo (2016), the current study was able to expect that hotel restaurant cook's job satisfaction would have significant effect on customer orientation. Therefore, the following hypotheses were established.

H3: Hotel restaurant cook's job satisfaction will have effect on customer orientation

H3a: Hotel restaurant cook's satisfaction on superior and coworker will have effect on customer orientation.

H3b: Hotel restaurant cook's satisfaction on compensation and promotion will have effect on customer orientation. 


\subsection{Constructive Definition of Variables}

\subsubsection{Constructive Definition of Hotel Restaurant Cook's Emotional labor}

Based on criteria used in studies done by Hochschild (1983), Ashforth and Humphrey (1993), Hochschild (1979), Grandey (2000), Zapf (2002), and Kwak (2015) to measure hotel restaurant cook's emotional labor, their reliability and validity were tested. As mentioned in theoretical background earlier, hotel restaurant cook's emotional labor was composed of two constructs, surface acting and deep acting, and each construct was measured with Likert 7point scale.

\subsubsection{Constructive Definition of Hotel Restaurant Cook's Job Satisfaction}

Based on criteria developed in studies done by Wendy et al. (2005), Jung (2014), and Yoo (2016) to measure hotel restaurant cook's job satisfaction, their reliability and validity were tested. As mentioned in theoretical background earlier, hotel restaurant cook's job satisfaction was composed of two constructs, satisfaction on superior and coworker and satisfaction on compensation and promotion, and each construct was measured with Likert 7point scale.

\subsubsection{Constructive Definition of Hotel Restaurant Cook's Customer Orientation}

Based on criteria developed in studies done by Periatt et al. (2007), Kim (2010), Lee (2012), and Jung (2014) to measure hotel restaurant cook's customer orientation, their reliability and validity were tested. As mentioned in theoretical background earlier, hotel restaurant cook's customer orientation was a construct, and it was measured with Likert 7-point scale.

\subsection{Composition of Survey}

Table 1 shows measurement variable and composition of survey used in the current study.

Table 1: Composition of Survey

\begin{tabular}{|c|c|c|c|c|}
\hline \multicolumn{2}{|c|}{ Measurement Variable } & Measurements & Questions & Reference \\
\hline \multirow{2}{*}{$\begin{array}{l}\text { Cook's } \\
\text { Emotional } \\
\text { labor }\end{array}$} & Deep Acting & $\begin{array}{l}\text { I try for positive emotional expression during } \\
\text { customer encounter, I try to keep positive } \\
\text { emotion, I try to have emotion to help customers } \\
\text { while working, I try to have positive impression } \\
\text { and emotion as desired by company, I try to feel } \\
\text { true emotion that needs to be expressed to } \\
\text { customers }\end{array}$ & 4 & $\begin{array}{c}\text { Hochschild (1979), } \\
\text { Grandey(2000), } \\
\text { Zapf(2002) }\end{array}$ \\
\hline & $\begin{array}{l}\text { Surface } \\
\text { Acting }\end{array}$ & $\begin{array}{l}\text { I treat customers while hiding my true emotion, } \\
\text { I exaggerate emotion that differs from my true } \\
\text { emotion, I express positive emotion on purpose } \\
\text { when encountering customers, I try to smile } \\
\text { even if it is different from my true emotion }\end{array}$ & 5 & Kwak (2015) \\
\hline $\begin{array}{c}\text { Job } \\
\text { Satisfaction }\end{array}$ & $\begin{array}{c}\text { Satisfaction } \\
\text { on Superior } \\
\text { and Coworker }\end{array}$ & $\begin{array}{l}\text { My superior recognizes autonomy in terms of } \\
\text { job performance, My superior helps with my } \\
\text { work, My superior compliments me when I } \\
\text { perform my work well, My coworkers are } \\
\text { willing to help when there is difficulty, My } \\
\text { coworkers in the same department work well } \\
\text { together }\end{array}$ & 5 & $\begin{array}{c}\text { Jung (2014), } \\
\text { Yoo(2016), } \\
\text { Wendyetal.(2006) }\end{array}$ \\
\hline
\end{tabular}




\begin{tabular}{|c|c|c|c|}
\hline $\begin{array}{c}\text { Satisfaction } \\
\text { on } \\
\text { Compensation } \\
\text { and } \\
\text { Promotion }\end{array}$ & $\begin{array}{l}\text { There is fair promotion in my hotel. Work } \\
\text { evaluation which affects promotion is carried } \\
\text { out fairly. I think my compensation is higher } \\
\text { than that of a person working in the same } \\
\text { department in different hotel. My compensation } \\
\text { is reasonable compared to my efforts. }\end{array}$ & 4 & \\
\hline Customer Orientation & $\begin{array}{l}\text { I try to provide service that would be helpful to } \\
\text { the customers in their shoes, I explain to } \\
\text { customers about a service as is, I try to have } \\
\text { conversation with customers frequently, I act } \\
\text { before customers ask for something, I answer as } \\
\text { honestly as possible to customer's questions. I } \\
\text { provide as much information as possible to } \\
\text { customer's need, I try to respond to customer's } \\
\text { need as fast as possible, I greet to customers } \\
\text { with a cheerful look }\end{array}$ & 8 & $\begin{array}{l}\text { Periatt et al. (2007), } \\
\text { Kim(2010), } \\
\text { Lee(2012), } \\
\text { Jung(2014) }\end{array}$ \\
\hline Demographics & $\begin{array}{l}\text { Gender, Age, Education, Income, Department, } \\
\text { Form of Employment, Work experience, } \\
\text { Position, Marital Status }\end{array}$ & 9 & Yoo (2016) \\
\hline
\end{tabular}

\subsection{Sampling and Data Collection}

In order to achieve the current study's goal, sample was extracted targeting cooks working in 5-start hotels located in Seoul considering spatial and time limitation. Method of research was direct research method with survey. Survey was conducted from April 1st, 2018 to April 20, 2018 (approximately 20 days). Total of 300 surveys were distributed to cooks working in 5-start hotels located in Seoul, and among those 250 surveys were returned. Among returned 250 surveys, 246 surveys (rate of surveys actually used: 82.00\%) - excluding four surveys answered insincerely - were used in the analysis.

As for the method of analysis, SPSSWIN 19.0, which was designed to analyze social science data, was used to analyze collected data. Major method of analysis includes frequency analysis, validity analysis, reliability analysis, correlation analysis, and multiple regression analysis. To enhance statistical power of the test of social science hypotheses, this study utilized general significance level, $\mathrm{p} \leq .05$.

\section{Results of Analysis}

\subsection{Demographical Characteristics of the Sample}

The result of frequency analysis on demographical characteristics of the sample is as shown in Table 2 .

Table 2: Demographical Characteristics of the Sample

\begin{tabular}{|c|l|c|c|}
\hline \multicolumn{2}{|c|}{ Classification } & Frequency & Percentage \\
\hline \multirow{3}{*}{ Gender } & Male & 185 & 75.2 \\
\cline { 2 - 5 } & Female & 61 & 24.8 \\
\hline \multirow{5}{*}{ Age } & $20 \mathrm{~s}$ & 80 & 32.5 \\
\cline { 2 - 5 } & $30 \mathrm{~s}$ & 111 & 45.1 \\
\cline { 2 - 5 } & $40 \mathrm{~s}$ & 49 & 19.9 \\
\cline { 2 - 5 } & $50 \mathrm{~s}$ & 8 & 2.4 \\
\hline \multirow{2}{*}{ Education } & High School Diploma & 85 & 3.3 \\
\cline { 2 - 5 } & (Some) Associate Degree & 8 & 34.6 \\
\hline
\end{tabular}




\begin{tabular}{|c|c|c|c|}
\hline & (Some) Bachelor's Degree & 73 & 29.7 \\
\hline & (Some or Above) Master's degree & 80 & 32.5 \\
\hline \multirow{5}{*}{ Income } & Above 1 Million Won - Below 2 Million Won & 74 & 30.1 \\
\hline & Above 2 Million Won - Below 3 Million Won & 98 & 39.8 \\
\hline & Above 3 Million Won - Below 4 Million Won & 49 & 19.9 \\
\hline & Above 4 Million Won - Below 5 Million Won & 6 & 2.4 \\
\hline & Above 5 Million Won & 19 & 7.7 \\
\hline \multirow{7}{*}{ Department } & Korean Kitchen & 47 & 19.1 \\
\hline & Chinese Kitchen & 12 & 4.9 \\
\hline & American Kitchen & 58 & 23.6 \\
\hline & Japanese Kitchen & 34 & 13.8 \\
\hline & Bakery Kitchen & 27 & 11 \\
\hline & Main Kitchen & 29 & 11.8 \\
\hline & Buffet Kitchen & 39 & 15.9 \\
\hline \multirow{2}{*}{$\begin{array}{c}\text { Form of } \\
\text { Employment }\end{array}$} & Permanent Employment & 176 & 71.5 \\
\hline & Contingent Employment & 70 & 28.5 \\
\hline \multirow{5}{*}{$\begin{array}{c}\text { Work } \\
\text { Experience }\end{array}$} & Below 1 Year & 39 & 15.9 \\
\hline & $1-5$ Years & 80 & 32.5 \\
\hline & $6-10$ Years & 50 & 20.3 \\
\hline & $11-15$ Years & 42 & 17.1 \\
\hline & Above 15 Years & 35 & 14.2 \\
\hline \multirow{4}{*}{ Position } & Assistant Cook & 29 & 11.8 \\
\hline & Cook & 152 & 61.8 \\
\hline & Sous-Chef & 45 & 18.3 \\
\hline & Main Chef & 20 & 8.1 \\
\hline \multirow{2}{*}{$\begin{array}{l}\text { Marital } \\
\text { Status }\end{array}$} & Single & 150 & 61 \\
\hline & Married & 96 & 39 \\
\hline & Total & 246 & 100 \\
\hline
\end{tabular}

\subsection{Reliability and Validity Test of Measurement Tool}

As a result of factor analysis on nine categories of hotel restaurant cook's emotional labor, as shown in Table 3, there were two factors with eigenvalue higher than 1, and the total variation of all factors was $65.982 \%$. In terms of subfactors, Factor 1 (37.597\%) was named 'deep acting' while Factor 2 (28.384\%) was named 'surface acting'. Also, factor load of the two factors was above .40 which verified constructs' validity, and reliability did not have any problem with its value of above .80 .

Table 3: Validity and Reliability Test of Hotel Restaurant Cook's Emotional labor

\begin{tabular}{|c|c|c|c|c|c|}
\hline Factor & Category & $\begin{array}{c}\text { Factor } \\
\text { Load }\end{array}$ & Eigenvalue & $\begin{array}{c}\text { Variance } \\
(\%)\end{array}$ & Reliability \\
\hline \multirow{4}{*}{$\begin{array}{l}\text { Factor 1: } \\
\text { Deep } \\
\text { Acting }\end{array}$} & $\begin{array}{l}\text { I try for positive emotional expression during } \\
\text { customer encounter. }\end{array}$ & 0.830 & \multirow{4}{*}{4.695} & \multirow{4}{*}{37.597} & \multirow{4}{*}{.854} \\
\hline & I try to keep positive emotion. & 0.784 & & & \\
\hline & $\begin{array}{l}\text { I try to have emotion to help customers while } \\
\text { working. }\end{array}$ & 0.748 & & & \\
\hline & $\begin{array}{l}\text { I try to have positive impression and emotion as } \\
\text { desired by company. }\end{array}$ & 0.739 & & & \\
\hline
\end{tabular}




\begin{tabular}{|c|c|c|c|c|c|}
\hline & $\begin{array}{l}\text { I try to feel true emotion that needs to be } \\
\text { expressed to customers. }\end{array}$ & 0.676 & & & \\
\hline \multirow{4}{*}{$\begin{array}{l}\text { Factor 2: } \\
\text { Surface } \\
\text { Acting }\end{array}$} & I treat customers while hiding my true emotion. & 0.866 & \multirow{4}{*}{1.243} & \multirow{4}{*}{28.384} & \multirow{4}{*}{.821} \\
\hline & $\begin{array}{l}\text { I exaggerate emotion that differs from my true } \\
\text { emotion. }\end{array}$ & 0.844 & & & \\
\hline & $\begin{array}{l}\text { I express positive emotion on purpose when } \\
\text { encountering customers. }\end{array}$ & 0.683 & & & \\
\hline & $\begin{array}{l}\text { I try to smile even if it is different from my true } \\
\text { emotion. }\end{array}$ & 0.584 & & & \\
\hline
\end{tabular}

*Factors with eigenvalue higher than 1 were extracted. Cumulative variance is $65.982 \%$.

As a result of factor analysis on nine categories of hotel restaurant cook's job satisfaction, as shown in Table 4, there were two factors with eigenvalue higher than 1, and the total variation of all factors was $65.290 \%$. In terms of subfactors, Factor 1 (32.861\%) was named 'satisfaction on superior and coworker' while Factor 2 (32.429\%) was named 'satisfaction on compensation and promotion'. Also, factor load of the two factors was above .40 which verified constructs' validity, and reliability did not have any problem with its value of above .80 .

Table 4: Validity and Reliability Test of Hotel Restaurant Cook's Job Satisfaction

\begin{tabular}{|c|c|c|c|c|c|}
\hline Factor & Category & $\begin{array}{c}\text { Factor } \\
\text { Load }\end{array}$ & Eigenvalue & $\begin{array}{c}\text { Variance } \\
(\%)\end{array}$ & Reliability \\
\hline \multirow{5}{*}{$\begin{array}{l}\text { Factor 1: } \\
\text { Satisfaction on } \\
\text { Superior and } \\
\text { Coworker }\end{array}$} & $\begin{array}{l}\text { My superior recognizes autonomy in terms } \\
\text { of job performance. }\end{array}$ & 0.806 & \multirow{5}{*}{4.465} & \multirow{5}{*}{32.861} & \multirow{5}{*}{.833} \\
\hline & My superior helps with my work. & 0.802 & & & \\
\hline & $\begin{array}{l}\text { My superior compliments me when I } \\
\text { perform my work well. }\end{array}$ & 0.747 & & & \\
\hline & $\begin{array}{l}\text { My coworkers are willing to help when } \\
\text { there is difficulty. }\end{array}$ & 0.712 & & & \\
\hline & $\begin{array}{l}\text { My coworkers in the same department } \\
\text { work well together. }\end{array}$ & 0.634 & & & \\
\hline \multirow{4}{*}{$\begin{array}{l}\text { Factor 2: } \\
\text { Satisfaction on } \\
\text { Compensation } \\
\text { and Promotion }\end{array}$} & There is a fair promotion in my hotel. & 0.864 & \multirow{4}{*}{1.411} & \multirow{4}{*}{32.429} & \multirow{4}{*}{.817} \\
\hline & $\begin{array}{l}\text { Work evaluation which affects promotion } \\
\text { is carried out fairly. }\end{array}$ & 0.860 & & & \\
\hline & $\begin{array}{l}\text { I think my compensation is higher than } \\
\text { that of a person working in the same } \\
\text { department in a different hotel. }\end{array}$ & 0.759 & & & \\
\hline & $\begin{array}{l}\text { My compensation is reasonable compared } \\
\text { to my efforts. }\end{array}$ & 0.757 & & & \\
\hline
\end{tabular}

*Factors with eigenvalue higher than 1 were extracted. Cumulative variance is $65.290 \%$.

As a result of factor analysis on eight categories of hotel restaurant cook's customer orientation, as shown in Table 5, there was one factor with eigenvalue higher than 1, and the total variation of all factors was $58.518 \%$. Factor $1(58.518 \%)$ was named 'customer orientation'. Also, factor load of the factor was above .40 which verified constructs' validity, and reliability did not have any problem with its value of above. 80 .

Table 5: Validity and Reliability Test of Hotel Restaurant Cook's Customer Orientation

\begin{tabular}{|c|c|c|c|c|c|}
\hline Factor & Category & $\begin{array}{l}\text { Factor } \\
\text { Load }\end{array}$ & Eigenvalue & $\begin{array}{c}\text { Variance } \\
(\%)\end{array}$ & Reliability \\
\hline \multirow{2}{*}{$\begin{array}{l}\text { Factor 1: } \\
\text { Customer } \\
\text { Orientation }\end{array}$} & $\begin{array}{l}\text { I try to provide service that would be helpful } \\
\text { to the customers in their shoes. }\end{array}$ & 0.805 & \multirow{2}{*}{4.681} & \multirow{2}{*}{58.518} & \multirow{2}{*}{.898} \\
\hline & I explain to customers about a service as is. & 0.782 & & & \\
\hline
\end{tabular}




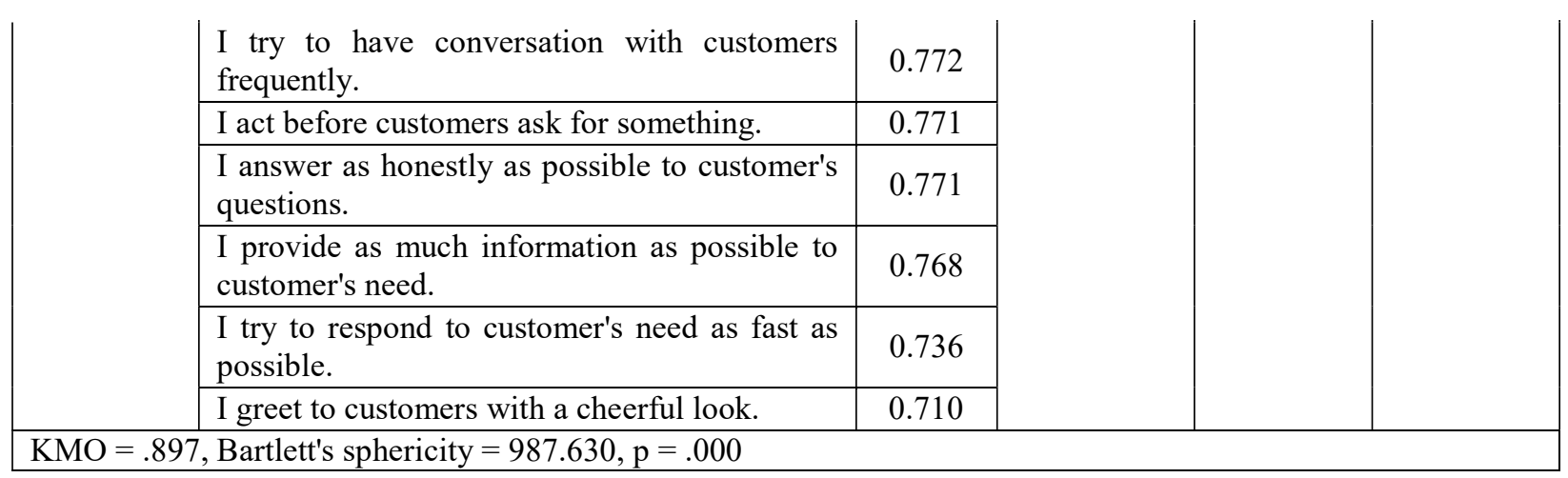

* Factors with eigenvalue higher than 1 were extracted. Cumulative variance is $58.518 \%$.

\subsection{Result of Correlation Analysis among Constructs}

Correlation analysis measures strength of primary relationship between two factors, and it represents primary direction and correlation between two variables. In general, Pearson correlation coefficient is used simply to refer to correlation coefficient. If there is a low correlation between two variables, they are mutually exclusive concepts which can be distinguished which verify their validity.

In this study, the result of correlation analysis of factors extracted from factor analysis is as shown in Table 6.

Table 6: Result of Correlation Analysis of the Constructs

\begin{tabular}{|l|l|l|l|l|l|l|l|}
\hline \multicolumn{1}{|c|}{ Factor } & Mean & $\begin{array}{l}\text { Standard } \\
\text { Deviation }\end{array}$ & \multicolumn{1}{|c|}{ (1) } & \multicolumn{1}{|c|}{ (2) } & (3) & (4) & (5) \\
\hline Deep Acting (1) & 4.01 & .60 & 1 & & & & \\
\hline Surface Acting (2) & 3.73 & .70 & $.59^{* *}$ & 1 & & & \\
\hline Satisfaction on Superior and Coworker (3) & 3.72 & .70 & $.58^{* *}$ & $.55^{* *}$ & 1 & & \\
\hline $\begin{array}{l}\text { Satisfaction on Compensation and } \\
\text { Promotion (4) }\end{array}$ & 3.03 & .97 & $.41^{* *}$ & $.44^{* *}$ & $.38^{* *}$ & 1 & \\
\hline Customer Orientation (5) & 3.92 & .59 & $.59^{* *}$ & $.66^{* *}$ & $.62^{* *}$ & $.50^{* *}$ & 1 \\
\hline
\end{tabular}

$* *$ Correlation coefficient is significant if above 0.01 (both directions)

\subsection{Hypothesis Testing}

\subsubsection{Effect of Hotel Restaurant Cook's Emotional labor on Job Satisfaction (Satisfaction on Superior and Coworker) (H1)}

The result of multiple regression analysis to test effect of hotel restaurant cook's emotional labor on job satisfaction (satisfaction on superior and coworker) is as shown in Table 7. As a result of analysis, explanation power of regression model was $38.0 \%$, and regression equation turned out to be statistically significant $(\mathrm{F}=73.790$, $\mathrm{p}<.001)$. As for independent variable, deep acting $(\beta=.544, \mathrm{p}<.01)$ had statistically significantly positive effect on job satisfaction (satisfaction on superior and coworker). Surface acting did not have a significant effect. As a result, as deep acting - a subfactor of hotel restaurant cook's emotional labor - increases, job satisfaction (satisfaction on superior and coworker) increases.

Table 7: Effect of Hotel Restaurant Cook's Emotional labor on Job Satisfaction

(Satisfaction on Superior and Coworker)

\begin{tabular}{|c|c|c|c|c|c|c|c|}
\hline \multirow{2}{*}{ Classification } & \multicolumn{2}{|c|}{$\begin{array}{l}\text { Unstandardized } \\
\text { Coefficient }\end{array}$} & \multicolumn{2}{|c|}{$\begin{array}{c}\text { Standardized } \\
\text { Coefficient }\end{array}$} & \multirow{2}{*}{ p-value } & \multicolumn{2}{|c|}{ Collinearity } \\
\hline & B & Standard Error & Beta & $\mathbf{t}$ & & Tolerance & VIF \\
\hline (constant) & .763 & .248 & & 3.076 & $.002 * *$ & & \\
\hline Deep Acting & .636 & .074 & .544 & 8.640 & $.000 * *$ & 1.000 & 1.000 \\
\hline Surface Acting & .111 & .063 & .110 & 1.753 & .081 & 1.000 & 1.000 \\
\hline
\end{tabular}

$* * \mathrm{p}<0.01$ 


\subsubsection{Effect of Hotel Restaurant Cook's Emotional labor on Job Satisfaction (Satisfaction on Compensation and Promotion) (H2)}

The result of multiple regression analysis to test effect of hotel restaurant cook's emotional labor on job satisfaction (satisfaction on compensation and promotion) is as shown in Table 8. As a result of analysis, explanation power of regression model was $14.5 \%$, and regression equation turned out to be statistically significant $(\mathrm{F}=20.398, \mathrm{p}<.001)$. As for independent variable, deep acting $(\beta=.252, \mathrm{p}<.01)$ and surface acting $(\beta=.172, \mathrm{p}$ $<.05$ ) had statistically significantly positive effect on job satisfaction (satisfaction on compensation and promotion). As a result, as deep acting and surface acting - subfactors of hotel restaurant cook's emotional labor - increase, job satisfaction (satisfaction on compensation and promotion) increases.

Table 8: Effect of Hotel Restaurant Cook's Emotional labor on Job Satisfaction

(Satisfaction on Compensation and Promotion)

\begin{tabular}{|c|c|c|c|c|c|c|c|}
\hline \multirow[t]{2}{*}{ Classification } & \multicolumn{2}{|c|}{$\begin{array}{l}\text { Unstandardized } \\
\text { Coefficient }\end{array}$} & \multicolumn{2}{|c|}{$\begin{array}{c}\text { Standardized } \\
\text { Coefficient }\end{array}$} & \multirow[t]{2}{*}{ p-value } & \multicolumn{2}{|c|}{ Collinearity } \\
\hline & B & Standard Error & Beta & $\bar{t}$ & & Tolerance & VIF \\
\hline (constant) & .556 & .397 & & 1.401 & .162 & & \\
\hline Deep Acting & .401 & .118 & .252 & 3.408 & $.001 * *$ & 1.000 & 1.000 \\
\hline Surface Acting & .236 & .101 & .172 & 2.329 & $.021^{* * *}$ & 1.000 & 1.000 \\
\hline
\end{tabular}

\subsubsection{Effect of Hotel Restaurant Cook’s Job Satisfaction on Customer Orientation (H3)}

The result of multiple regression analysis to test effect of hotel restaurant cook's job satisfaction on customer orientation is as shown in Table 9. As a result of analysis, explanation power of regression model was 33.3\%, and regression equation turned out to be statistically significant $(\mathrm{F}=59.561, \mathrm{p}<.001)$. As for independent variable, satisfaction on superior and coworker $(\beta=.535, \mathrm{p}<.01)$ had statistically significantly positive effect on customer orientation. Satisfaction on compensation and promotion did not have a significant effect. As a result, as satisfaction on superior and coworker - a subfactor of hotel restaurant cook's job satisfaction - increases, customer orientation increases.

Table 9: Effect of Hotel Restaurant Cook's Job Satisfaction on Customer Orientation

\begin{tabular}{|c|c|c|c|c|c|c|c|}
\hline \multirow{2}{*}{ Classification } & \multicolumn{2}{|c|}{$\begin{array}{c}\text { Unstandardized } \\
\text { Coefficient }\end{array}$} & \multicolumn{2}{|c|}{ Standardized Coefficient } & \multirow{2}{*}{ p-value } & \multicolumn{2}{|c|}{ Collinearity } \\
\hline & B & $\begin{array}{l}\text { Standard } \\
\text { Error }\end{array}$ & Beta & t & & Tolerance & VIF \\
\hline (constant) & 2.134 & .166 & & 12.829 & .000 & & \\
\hline $\begin{array}{l}\text { Satisfaction on } \\
\text { Superior and } \\
\text { Coworker }\end{array}$ & .443 & .052 & .535 & 8.572 & $.000^{* *}$ & 1.000 & 1.000 \\
\hline $\begin{array}{l}\text { Satisfaction on } \\
\text { Compensation } \\
\text { and Promotion }\end{array}$ & .044 & .038 & .072 & 1.146 & .253 & 1.000 & 1.000 \\
\hline
\end{tabular}

\section{Conclusion and Suggestion}

This study analyzes effect of hotel restaurant cook's emotional labor on job satisfaction. It also analyzes effect of job satisfaction on customer orientation. Based on the analysis, the current study aims to provide aid in enhancing hotel restaurant cook's core competence and managing hotel restaurant cook's human resources more efficiently. In order to achieve the current study's goal, a direct research method with survey was selected. Survey was conducted from April 1st, 2018 to April 20, 2018 (approximately 20 days). Total of 300 surveys were distributed, and among those 246 surveys were returned and used in the analysis. 
The following are the result of the analysis. First, in order to test H1, multiple regression analysis on effect of hotel restaurant cook's emotional labor on satisfaction on superior and coworker was performed. As a result, deep acting had significant effect while surface acting did not have significant effect. Second, in order to test H2, multiple regression analysis on effect of hotel restaurant cook's emotional labor on satisfaction on compensation and promotion was performed. As a result, all variables - deep acting and surface acting - had significant effect. Third, in order to test $\mathrm{H} 3$, simple regression analysis on effect of hotel restaurant cook's job satisfaction on customer orientation was performed. As a result, satisfaction on superior and coworker had significant effect while satisfaction on compensation and promotion did not have significant effect.

The following are theoretical implications of the current study.

First, according to preceding researches, there have been numerous researches targeting hotel restaurant cooks; however, it is hard to find one that analyzes causal relationship among hotel restaurant cook's emotional labor, job satisfaction, and customer orientation. In this point, the current study can be differentiated from the existing studies. Second, it is meaningful to discover that deep acting has the most effect on hotel restaurant cook's job satisfaction. In other words, to enhance hotel restaurant cook's job satisfaction, hotel restaurant cooks should make an effort to have positive feeling and emotion about each other. Also, they will have high job satisfaction if they try to have positive emotion and feel true emotion which will heighten their deep acting.

The following are practical implications of the current study.

First, to test H1, effect of hotel restaurant cook's emotional labor on job satisfaction (satisfaction on superior and coworker) was analyzed; as a result, while deep acting had a statistically significantly positive effect on job satisfaction (satisfaction on superior and coworker), surface acting did not have a statistically significant effect. This implies that hotel restaurant cooks try to express their positive emotion or maintain it. Also, they try to have positive impression and emotion themselves.

Second, to test H3, effect of hotel restaurant cook's emotional labor on job satisfaction (satisfaction on compensation and promotion) was analyzed; as a result, deep acting and surface acting had a statistically significantly positive effect on job satisfaction (satisfaction on compensation and promotion). This implies that cooks try to have an emotion of assisting customers and feel true emotion to customers. Cooks also encounter customers while hiding their true emotion and try to express positive feeling on purpose.

Third, to test H3, effect of hotel restaurant cook's job satisfaction on customer orientation was analyzed; as a result, while satisfaction on superior and coworker had a statistically significantly positive effect on customer orientation, satisfaction on compensation and promotion did not. This implies that satisfying internal customers superior and coworker - is essential in satisfying external customers, rather than trying to satisfy external customers directly. In the end, in terms of customer satisfaction, satisfaction on superior and coworker is more important than satisfaction on compensation and promotion.

The following are the limitations and suggestions for future studies. First, as the current study targeted cooks working in 5-star hotels located in Seoul, there is limitation in generalizing the result. I the future it would be easier to generalize the result if researches are conducted targeting hotel restaurant cooks around the country.

Second, as the current study relies on survey, it is unavoidable that the result is dependent on survey respondent's answer. As hotel restaurant cooks are busy, there can be reluctance in answering surveys with a lot of questions. In order to overcome this difficulty, deeper analysis utilizing Delphi technique can be considered.

\section{Reference}

Adelamann, P. K. (1989). Emotional labor of employee well-being. University of Michigan.

Allen, J. A., Push, S. D., Grandey, A. A., \& Groth, M. (2010). Following display rules in good or bad faith? customer orientation as a moderator of display rule-emotional labor relationship. Human Performance, 23(2), 101-115.

Ashforth, B. E. \& R. H. Humphrey (1993). Emotional labor in service roles: the influence of identity. Academy of Management Review, 18(1), 88-115.

Baek, H. S., shin, C. S., \& Lee, S. Y. (2016). The analysis of a causal relationship of traditional Korean restaurant's well-being attribute selection on customers' re-visitation and word-of-mouth. East Asian Journal of Business Economics, 4(2), 48-60.

Baik, S. H. (2003). Study on hairstylist's emotional labor, exhaustion, and job satisfaction. Inge, Korea: Doctorial dissertation, University of Inje.

Brotheridge, C. M., \& Grandey, A. A. (2002). Emotional labor and burnout: comparing two perspectives of people work. Journal of Vocational Behavior, 60(1), 17-39. 
Brown, T. J., Mowen, J. C., Donavan, D. T., \& Licata, J. W. (2002). The customer orientation of service workers: personality trait determinants and effects on self and supervisor performance ratings. Journal of Marketing Research, 39(2), 110-119.

Chang, H. J., \& Lee, D. J. (2011). Study on food ingredient purchase system and management for hotel's effective management of cost. Journal of Korea Hotel \& Resort Association, 10(1), 79-93.

Cho, C. B., Kim, Y. K., \& Chae, B. S. (2006). Effect of kitchen system - depending on hotel management - on worker's job satisfaction. Journal of Foodservice Management, 9(2), 129-148.

Choi, H. S., Lim, H. C., \& Jung, M. K. (2008). Study on predisposing factors of cell center worker's emotional labor. Korean Corporation Management Review, 15(2), 53-68.

Day, G. S., \& Wensley, R. (1988). Assessing advantage: a framework for diagnosing competitive superiority. Journal of Marketing, 52(2), 1-20.

Donavan, D. T., Brown, T. J., \& Mowen, J. C. (2004). Internal benefits of service-worker customer orientation: job satisfaction, commitment, and organizational citizenship behaviors. Journal of Marketing, 68(1), 128-146.

Fisher, C. D. (2000). Mood and emotions while working: missing pieces of job satisfaction? Journal of Organizational Behavior, 2, 185-186.

Grandey, A. (2000). Emotional regulation in the workplace: a new way to conceptualize emotional labor. Journal of Occupational Health Psychology, 5(1), 95-110.

Hochschild, A. (1983). The managed heart: the commercialization of human feeling. Berkeley: University of California Press.

Hoppock, R (1935). Job Satisfaction. NY: Harper \& Row.

Hwang, G. S., Jung, H. J., Kim, H. R.,shin, C. S. (2017). The effects of business startup education of restaurant founder on transfer effect in learning and entrepreneurial intentions. East Asian Journal of Business Economics, 5(4), 20-38.

Hwang, G. S., Kim, H. S., \& Park, D. S. (2017). The analysis on causal relationship between business startup education and entrepreneurial intention. Journal of Distribution Science, 15(3), 29-39.

Jun, S. Y. (2015). Study on effect of member's emotional labor on job satisfaction and mediating effect of organizational support recognition. Korean Journal of Business Administration, 28(12), 3235-3255.

Jung, T. Y. (2014). Effect of flight attendant's occupational stress on organization effectiveness, customer orientation, and intention to change job. Kyounggi, Korea: Doctorial dissertation, Kyonggi University.

Kim, B. K. (2006). Study on tourism hotel worker's job satisfaction. Journal of Tourism, 30(2), 217-236.

Kim, K., \& Han, K. M. (2012). Effect of police officer's emotional labor on occupational stress and job satisfaction: based on J police station. Study of Korean Society and Administration, 22(4), 497-523.

Kim, L. (2004). Effect of customer service engagement on recognition of service quality. Seoul, Korea: Doctorial dissertation, Yonsei University.

Kim, S. H. (2010). Effect of intimacy among cabin crews on customer orientation. Seoul, Korea: Doctorial dissertation, Sejong University.

Kim, Y. J., \& Choi, W. H. (2017). Effect of organizational culture recognized by hotel workers on job satisfaction and intention to change jobs: test of difference between forms of employments. Journal of Foodservice Management, 20(3), 237-257.

Kim, Y. J., \& Jung, Y. J. (2019). Effect of job autonomy recognized by hotel foodservice worker on job crafting and job satisfaction. Journal of Foodservice Management, 22(3), 87-105.

Ko, J. W. (2013). Study on social worker's emotional labor: focused on social worker in adult daycare center. Korea Academy of Care Management, 9(1), 65-94.

Kong, K. Y., Won, C. S., \& Chang, B. J. (2007). Relation among hotel's service orientation, job satisfaction, and organizational commitment. Study of Tourism, 24(5), 39-154.

Kwak, E. Y. (2003). Behavior Theory of New Organization. Chongmok Press.

Lee, C. E., \& Lee, J. Y. (2010). Influential relationship among hotel worker's big 5 personalities, job engagement, and customer orientation. The Journal of the Korea Contents Association, 10(7), 386-395.

Lee, M. K. (2012). Effect of cabin crew team's organization atmosphere on customer orientation. Journal of the Aviation Management Society of Korea, 10(2), 119-138.

Lee, S. W., shin, C. S., Junh, H. J. (2017). Analysis of causal relationship between Chinese restaurant chefs' work environment and burnout: focused on moderation role of enthusiasm. East Asian Journal of Business Economics, 5(4), 1-19.

Lee, Y. S. (2004). Effect of individual's personality and job conformance on job engagement. Seoul, Korea: Thesis for Doctorate in Korea University. 
Lee. D. W., Lee, H. S., \& Lee, S. B. (2008). Effect of hotel kitchen's cooperation environment and layout on satisfaction on kitchen work environment, recognition on organizational support, and job satisfaction. Journal on Hotel Management, 17(1), 89-105.

Loke, E. A. (1976). The nature and causes of job satisfaction. In M.D. Dunnette (Ed). Handbook of industrial and organization psychology, (pp.1297-1343), Chicago: Rand McNally.

Mccornick, E. S., \& D. Ilgen. (1980). Industrial Psychology (7th ed.). New Jersey: Prentice-Hall.

Periatt, J. A., Chakrabarty, S., \& Lemay, S. A. (2007). Using Personality Traits to Select Customer-oriented Logistic Personnel. Transportation Journal, 46(1), 22-37.

Rafaeli, A., \& Sutton I. (1988). The expression of emotion as part of the work role. Academy of Management Review, 12(1), 23-37.

Seo, K. Y. (2019). Effect of tourism worker's psychological capital on customer orientation: focusing on mediating effect of job satisfaction. Journal of Foodservice Management, 22(3), 241-265.

Smith, W. J., howard, J. T., \& Harringtin, K. V. (2005). Essential formal mentor characteristics and functions in governmental and nongovernmental organizations from the program administrator's and the mentor's perspective. Public Personnel Management, 34(1), 31-58.

Umunnakwe, C., \& Kim, G. B. (2019). The impacts of service quality, satisfaction, trust on customer loyalty for mobile operators in Nigeria. East Asian Journal of Business Economics, 7(2), 31-41.

Wharton, A. S. (1993). The affective consequences of service work. Work and Occupations, 20(1), 205-232.

Woo, S. K., Seo, Y. H., \& Cho, S. B. (2012). Effect of hotel worker's job conflict on customer orientation. Journal of Hotel Management, 21(3), 37-49.

Yoo, S. S. (2016). Study of structural influencing relationship between cabin crew's individual capability and customer orientation: focusing on mediating effect of organizational engagement. Journal of the Aviation Management Society of Korea, 14(6), 81-101.

Zapf, D. (2002). Emotional work and psychological well-being: A Review of the Literature and Some Conceptual considerations. Human Resource Management Review, 12(2), 237-268. 